\title{
INFLUENCE OF HEATING ELEMENTS DYNAMICS ON ENERGY SAVINGS
}

\author{
O. ŠIKULA ${ }^{1, *}$, O. LADJEDEL $L^{2}$, P. CHARVÁT ${ }^{3}$, L. ADJLOUT ${ }^{2}$, S. A. REFFAS ${ }^{2}$ \\ ${ }^{1}$ Faculty of Civil Engineering, Brno University of Technology, Veveř́ 331/95, Brno 602 00, Czech Republic \\ ${ }^{2}$ Mechanical Engineering Faculty, Université des Sciences et de la Technologie d'Oran Mohamed Boudiaf, Algeria \\ ${ }^{3}$ Faculty of Mechanical Engineering, Brno University of Technology, Czech Republic \\ *E-mail: sikula.o@vutbr.cz
}

\begin{abstract}
Dynamic heating computer simulations of one model typical living room heated alternatively by two types of heating bodies are presented in this paper. This contribution describes a numerical model of two heating elements (plate radiator and a new type of convector) showing different thermal inertia by using the TRNSYS software. The results show energy savings approximately of $10 \%$ for the new tested convector, where the thermal comfort is better in terms of reaching the required room temperature.
\end{abstract}

Keywords: heating radiators, thermal inertia, energy savings, software TRNSYS

\section{Introduction}

Pressure to reduce the energy performance of buildings, embodied in current regulations or technical standards, forces the professional public to look for heat savings in all areas of energy management in buildings and their energy systems $[10,11]$. Basic dynamic behavior of heating surfaces, or heating bodies are dealt with by a number of publications based on experiments or detailed CFD simulations [6-9]. These researches are mainly focused on basic transient phenomena and not on energy savings. Another publication presents an experimental validation of a numerical model of transient behaviour of heating surfaces by experiments [5].

Some researches dealing with energy savings achieved by the proper use of Thermostatic Valve (TRV) $[2,4]$ but do not treat the thermal inertia of heating bodies.

There are other publications dealing with room, radiator and TRV simulations, simplifying a thermal behaviour of a heating body to a lumped model - [1], state space and thermal resistance models - [3], but are not based on up-to-date detailed CFD simulations.

The present contribution focuses on the quantification of energy savings in the dynamic operation of heating radiators (HR) using TRSYS simulations of room and radiator thermal behaviour based on CFD simulations. This paper compares two heating bodies in a heated room under chosen dynamic operation conditions.

\section{Theory of dynamic heating of buildings}

In general, the need for heat output for room heating varies over time due to an influence of changing in heat losses, heat gains, and a user control. If the entire heating system is capable of responding accurately to these changes, the interior heating temperature is always exactly the required one and there is no temporary insufficient heating or overheating of the heated room. It is obvious, that every overheating is also automatically associated with a certain increased heat consumption.

This is an open-access article distributed under the terms of the Creative Commons Attribution-NonCommercial 4.0 International License (https://creativecommons.org/licenses/by-nc/4.0/), which permits unrestricted use, distribution, and reproduction in any medium for non-commercial purposes, provided the original author and source are credited, a link to the CC License is provided, and changes - if any - are indicated. 
From the physical point of view, all the heating surfaces exhibit, differently, the heat inertia rate during heating up and shut-down, and thus show a certain degree of under-heating or over-heating in a room. It is obvious that the greater the thermal inertia of the heating surface is, the more significant the above mentioned phenomena are.

\section{Definition of the case}

The effect of hot water radiators thermal inertia was assessed by computer simulation of the thermal behavior for a typical room using the TRNSYS computer simulation code.

\subsection{Specification of simulated radiators}

Two different types of radiators - plate radiator [13] and a convector, [14] - of, about the same, heating output were chosen. The basic specification and comparison are shown in Table 1. It is worth noting, it is clearly seen that there a twice bigger compactness of the convector (heating output per $\mathrm{m}^{3}$ of radiator volume).

Quantitative regulation of heating output is envisaged by a thermostatic valve for both radiators. The thermostatic valve is, for simplification, considered to be responding extremely quickly to the changing required temperature of the interior. It is assumed that we have a heating water at a constant temperature of $75{ }^{\circ} \mathrm{C}$ at the radiator inlet. These simplifications are taken to exclude the control system influence and to be considered only the influence of the radiator thermal inertia/dynamics.

\subsection{Specifications of the heated room}

The chosen room today is a common living room with 2 chilled walls and a window with a floor area of $20 \mathrm{~m}^{2}$. The thermal and technical properties meet the requirements of the thermal resistance standard, and ventilation with infiltrations with a constant air exchange rate of $n=0.5 \mathrm{~h}^{-1}$ is considered.

\subsection{Specification of boundary conditions}

Simulations of 2 cases were performed - further [17]. Initially, a simplified shutdown simulation (jumpoff of the heating water to the radiators) was performed to compare the maximum unwanted room overheating, due to their different heat capacity, at a constant room temperature of $20^{\circ} \mathrm{C}$.

Subsequently, a thermal behavior and heat consumption simulations were performed for the typical winter day. A sunny January day with an average outdoor air temperature of $+2.2{ }^{\circ} \mathrm{C}$ in South Moravia was chosen to simulate thermal behavior. In the room the desired interior temperature was selected as shown in Table 2. The initial temperature of the room has been set to $19^{\circ} \mathrm{C}$.

The dynamics of the thermal behavior of the compared radiators were determined by the detailed non-stationary CFD simulation by their heating up and shut-down. The obtained results in this CFD simulation were used to create simplified 1D models of both OTs in the TRNSYS software. The simplified model can, among other things, distinguish thermal energy supplying by heating water to the radiator and the heating energy supplied by the radiator to the room.

\section{Results and discussion}

A comparison of the heat capacity of the radiators and the thermal energy delivered to the heated room during shutdown (jump off of the heating water supply) at a constant ambient temperature of $20^{\circ} \mathrm{C}$ is shown in Table 3.

The obtained value of $77 \%$ is the theoretical, highest achievable heat savings when the convector is

Table 1. Specification of simulated radiators

\begin{tabular}{lccccc}
\hline Specification & Type & $\begin{array}{c}\text { Heating output } \\
\text { at } 75 / 65 / 20^{\circ} \mathrm{C}\end{array}$ & $\begin{array}{c}\text { Dimensions (height } / \\
\text { length } / \text { depth) }\end{array}$ & Compactness & Connecting way \\
\cline { 2 - 5 } & & {$[\mathrm{W}]$} & {$[\mathrm{mm}]$} & {$\left[\mathrm{kW} / \mathrm{m}^{3}\right]$} & \\
\hline $\begin{array}{l}\text { RADIK 20S CLEAN } \\
80 / 90 \mathrm{~cm}\end{array}$ & Plate radiator & 1170 & $900 / 800 / 100$ & 16.3 & $\begin{array}{l}\text { double-sided, } \\
\text { diagonal }\end{array}$ \\
\hline $\begin{array}{l}\text { Tomton R1 with } \\
\text { forced convection }\end{array}$ & Convector & 1216 & $570 / 502 / 135$ & 31.5 & bottom connection \\
\hline
\end{tabular}

Table 2. Distribution of required temperature during a typical day

\begin{tabular}{lcccc}
\hline Activity & Sleep & Morning activity & Non occupied & Evening activity \\
\hline Time $[\mathrm{h}]$ & $21: 00-4: 00$ & $4: 00-6: 00$ & $6: 00-16: 00$ & $16: 00-21: 00$ \\
Required temperature $\left[{ }^{\circ} \mathrm{C}\right]$ & $19{ }^{\circ} \mathrm{C}$ & $20{ }^{\circ} \mathrm{C}$ & $17^{\circ} \mathrm{C}$ & $20^{\circ} \mathrm{C}$ \\
\hline
\end{tabular}


Table 3. Heat capacity of radiators and the corresponding amount of heat delivered to the room

\begin{tabular}{lccc}
\hline & Thermal capacity & $\begin{array}{c}\text { Duration of the shutdown } \\
3000 \mathrm{~s}\end{array}$ & $\begin{array}{c}\text { Duration of the shutdown } \\
10000 \mathrm{~s}\end{array}$ \\
\cline { 2 - 4 } & $C$ & $E$ & $E$ \\
\cline { 2 - 4 } & {$[\mathrm{J} / \mathrm{K}]$} & {$[\mathrm{kWh}]$} & {$[\mathrm{kWh}]$} \\
\hline Plate radiator & 38259.04 & 0.082 & 0.600 \\
Convector & 8845.90 & 0.020 & 0.148 \\
Energy saving [\%] & $77 \%$ & $76 \%$ & $75 \%$ \\
\hline
\end{tabular}

Table 4. Temperatures and overheating during the test day

\begin{tabular}{|c|c|c|c|c|c|}
\hline \multirow{3}{*}{ OT } & $\begin{array}{l}\text { Room tempera- } \\
\text { ture at } 0 \mathrm{~h}\end{array}$ & $\begin{array}{l}\text { Room tempera- } \\
\text { ture at 24:00 }\end{array}$ & $\begin{array}{l}\text { Room temperature } \\
\text { real average per day }\end{array}$ & $\begin{array}{l}\text { Room temperature } \\
\text { required average per day }\end{array}$ & $\begin{array}{c}\text { Average room } \\
\text { overheating per day }\end{array}$ \\
\hline & $T$ & $T$ & $T$ & $T$ & $\Delta T$ \\
\hline & {$\left[{ }^{\circ} \mathrm{C}\right]$} & {$\left[{ }^{\circ} \mathrm{C}\right]$} & {$\left[{ }^{\circ} \mathrm{C}\right]$} & {$\left[{ }^{\circ} \mathrm{C}\right]$} & {$[\mathrm{K}]$} \\
\hline Plate radiator & 19.00 & 18.69 & 18.74 & 18.33 & 0.41 \\
\hline Convector & 19.00 & 18.24 & 18.55 & 18.33 & 0.21 \\
\hline
\end{tabular}

Table 5. Heat energy balance for the test day

\begin{tabular}{|c|c|c|c|c|c|c|}
\hline & $\begin{array}{l}\text { Heat delivered } \\
\text { to the radiator }\end{array}$ & $\begin{array}{l}\text { Heat delivered } \\
\text { to the room }\end{array}$ & $\begin{array}{l}\text { Transmission heat } \\
\text { losses of the room }\end{array}$ & $\begin{array}{l}\text { Ventilation heat } \\
\text { losses of the room }\end{array}$ & $\begin{array}{l}\text { Solar heat } \\
\text { gains }\end{array}$ & $\begin{array}{l}\text { Room energy } \\
\text { change per day }\end{array}$ \\
\hline & $E$ & $E$ & $E$ & $E$ & $E$ & $E$ \\
\hline & {$[\mathrm{kWh}]$} & {$[\mathrm{kWh}]$} & {$[\mathrm{kWh}]$} & {$[\mathrm{kWh}]$} & {$[\mathrm{kWh}]$} & {$[\mathrm{kWh}]$} \\
\hline Plate radiator & 12.64 & 12.40 & 9.07 & 2.00 & 0.073457 & 1.40 \\
\hline Convector & 11.16 & 11.16 & 8.97 & 1.98 & 0.075702 & 0.29 \\
\hline Saving [\%] & $11.7 \%$ & $10.1 \%$ & $1.2 \%$ & $1.2 \%$ & $3.0 \%$ & $79.4 \%$ \\
\hline
\end{tabular}

used instead of the plate radiator during one shutdown course (theoretical). The saving will always depend on the dynamics of changes in the required heating output in the reality. The smaller the changes in reality become, the smaller the savings will be.

The results of the simulations for the typical winter day are shown in the following tables and graph. Table 4 shows both the desired and achieved temperatures and the average room overheating rate. It can be seen that a room heated by a more dynamic radiator - convector shows a more precise adherence to the desired room temperature and also a lower average unwanted overheating.

Table 5 summarizes the essential components of the room's thermal balance over the test day.

The results show that, although plate radiator has slightly lower heating output (compared to the convector), due its higher thermal inertia, it supplies more heat to the room, hence increases its overall heat loss. Because of the higher average room temperature obtained, when we are using the plate radiator, a lower degree of utilization of solar gains of the room is observed.
However, the most significant result is the heat savings of $\sim 10 \%$ when the convector is used instead of the plate radiator.

The course of all significant variables for both heating modes of the room is shown in Fig. 1. The green areas present the heat savings using the convector, the red areas present the heat savings using the plate radiator.

\section{Conclusion}

The achieved results of the selected room by a more dynamic radiator (convector) show in this case:

- Lower heat loss of the room by transmission;

- Lower heat losses of the room by infiltration;

- Higher degree of utilization of solar gains of the room of $\sim 3 \%$;

- Lower average room overheating by $\sim 0.2 \mathrm{~K}$;

- Heat energy savings for heating $\sim 10 \%$. 


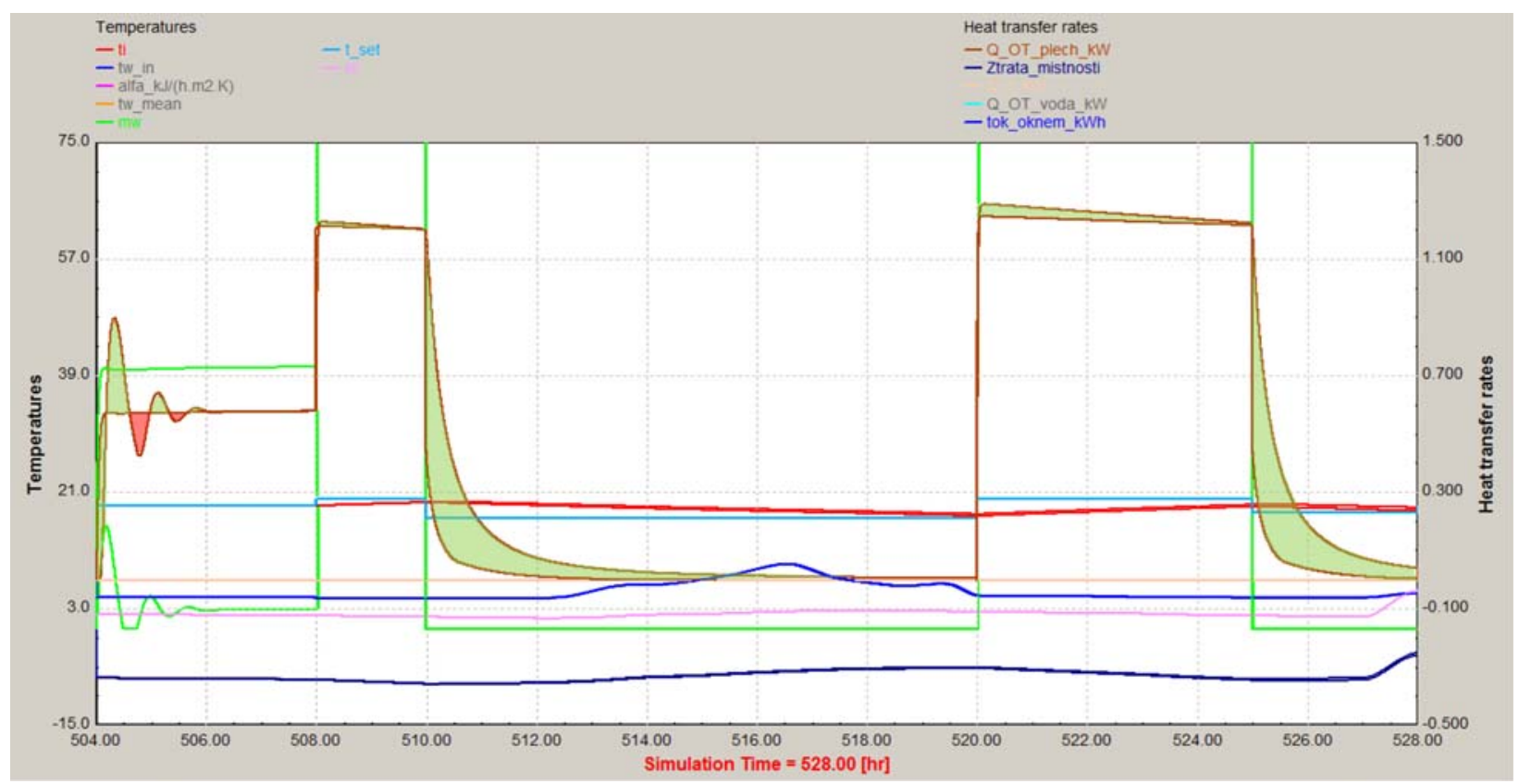

Fig. 1. The course of temperatures and heat fluxes during the test day

\section{Acknowledgements}

This work was supported by the Ministry of Education, Youth and Sports Czech Republic project No. LO1408 "AdMaS UP - Advanced Materials, Structures and Technologies" under the "National Sustainability Programme I".

\section{References}

[1] Xu, B., Fu L., Di H. (2008), Dynamic simulation of space heating systems with radiators controlled by TRVs in buildings. Energy and Buildings. Department of Building Science, School of Architecture, Tsinghua University, Beijing, 100084, China, 40(9), 1755-1764. DOI: $10.1016 /$ j.enbuild.2008.03.004. Dostupné také z: https://www.scopus.com/inward/record.uri?eid=2-s2.044349156989\&doi $=10.1016 \% 2$ fj.enbuild 2008.03 .004 $\&$ partnerID $=40 \&$ m d $5=2159$ defe 36 d 42 e 6327b356980a844201

[2] Monetti V., Fabrizio E., Filippi M. (2015), Impact of low investment strategies for space heating control: Application of thermostatic radiators valves to an old residential building: Application of thermostatic radiators valves to an old residential building. Energy and Buildings, DENERG, Politecnico di Torino, Corso Duca degli Abruzzi 24, Torino, Italy, 95, 202-210. DOI: 10.1016/j.enbuild.2015.01.001. Dostupné také z: https://www.scopus.com/inward/record. uri?eid=2-s2.0-84939959517\&doi $=10.1016 \% 2 \mathrm{fj}$. enbuild. 2015.01.001\&partnerID $=40 \& \mathrm{md} 5=\mathrm{d} 2 \mathrm{c} 9 \mathrm{ea} 09 \mathrm{a} 01 \mathrm{c} 881 \mathrm{ad} 7$ $1 \mathrm{a} 7 \mathrm{~d} 15 \mathrm{a} 86 \mathrm{ea} 403$

[3] Ning B., Schiavon S., Bauman F. S. (2017), A novel classification scheme for design and control of radiant system based on thermal response time. Energy and Buildings, 137, 38-45. DOI: https://doi.org/10.1016/j. enbuild.2016.12.013. ISSN 03787788. Dostupné také z: http://www.sciencedirect.com/science/article/pii/ S0378778816317583

[4] Boss B. (2015), Thermostatic radiator valves for multiunit residential buildings. HPAC Heating, Piping, AirConditioning Engineering. Danforss, Baltimore, MD, United States, 87(7), 16-20. Dostupné také z: https://www.scopus.com/inward/record.uri?eid=2-s2.0$84939864546 \&$ partnerID $=40 \& \mathrm{md} 5=2 \mathrm{~b} 1 \mathrm{c} 481451 \mathrm{fb} 37 \mathrm{dc}$ 1c117f01ead926fb

[5] Thomas S., Franck P.-Y., André P. (2011), Model validation of a dynamic embedded water base surface heat emitting system for buildings. Building Simulation, 4(1), 4148. DOI: 10.1007/s12273-011-0025-8. ISSN 19968744. Dostupné také z: http://dx.doi.org/10.1007/s12273-0110025-8

[6] Boháč J., Bašta J. (2016), Temperature fields dynamic of panel radiators. Vytapeni, Vetrani, Instalace. ČVUT v Praze, Fakulta Strojní, Ústav Techniky Prostředí, Czech Republic, 25(1), 2-5. Dostupné také z: https://www.scopus. com/inward/record.uri?eid=2-s2.0-84957661819\&partner ID=40\&md5=eec3adbf0a1321063d6573b1968541f6

[7] Bašta J., Vavřička R. (2006), Otopné plochy (I): Charakteristiky otopných těles. TZB-info [online]. 2006(2006), 1-9. ISSN 1801-4399.

[8] Jančík L., Bašta J. (2008), Setrvačnost náběhu a chladnutí otopných těles. TZB- info [online]. 2008(1), 1-3. ISSN 1801-4399.

[9] Jančík L., Bašta J. (2008), Posouzení dynamického chování otopných těles termografickou metodou. In: Jaroš, M. (Ed.). Simulace budov a technika prostředí 2008: Sborník 5. konference IBPSA-CZ. Praha: Česká technika - nakladatelství ČVUT, pp. 45-48. ISBN 978-80-254-3373-7.

[10] Petráš D. (2001), Nízkoteplotné vykurovanie a obnovitel'né zdroje energie. Bratislava: Jaga group, 271 p. ISBN 80-889-0512-5.

[11] Recknagel H., Sprenger E., Schramek E. (2001), Taschenbuch für Heizung und Klimatechnik (Handbook of Heat- 
ing and Air-conditioning Technology). 70. Auf. München: Oldenbourg, 2017 s. ISBN 34-862-6450-8.

[12] Šikula O. (2011), Simulace provozních režimů otopných systémů s velkou akumulací. Vytapeni, Vetrani, Instalace. Praha, 2011(5), 12-14.

[13] Šikula O., Plášek J. (2010), Vliv nočního útlumu vytápění na roční potřebu tepla. Vytápění, větrání, instalace: odborný časopis Společnosti pro techniku prostředí. Praha: Společnost pro techniku prostředí, 19(3), 124-130. ISSN 1210-1389.

[14] Radik desková otopná tělesa. Katalog výrobce 12/2016. Korado, a.s. Česká Třebová. Dostupné z: https://www. korado.cz/produkty/radik.html

[15] Radiátor TOMTON R1. Technická specifikace. Dostupné z: http://www.tomton-radiators.com/produkt/radiatortomton-r1/
[16] Šikula O., Charvát P., Adjlout L.; Ladjedel O. (2017), Modeling of radiators with mass flow control. In: Buildings and Environment: From Research to Application. Applied Mechanics and Materials. Switzerland: Trans Tech Publications, pp. 1-8. ISBN: 978-3-0357-1202- 5. ISSN: 1662-7482.

[17] Šikula, O., Charvát, P., Rozehnal, D. (2017), Dynamika otopných těles a jejich vliv na spotřebu tepla. In: Konference Vytápění Třeboň 2017. Novotného lávka 5, Praha 1 (ČSVTS): Společnost pro techniku prostředí, pp. 214218. ISBN: 978-80-02-02712-6. 